\title{
Mononuclear Cell Infiltration and Its Relation to the Expression of Major Histocompatibility Complex Antigens and Adhesion Molecules in Pancreas Biopsy Specimens from Newly Diagnosed Insulin-dependent Diabetes Mellitus Patients
}

\author{
Naoto Itoh, * Toshiaki Hanafusa, * Atsushi Miyazaki, * Jun-ichiro Miyagawa, * Kazuya Yamagata, * \\ Koji Yamamoto, * Masako Waguri, * Akihisa Imagawa, * Shinji Tamura, * Masami Inada, * \\ Sumio Kawata, * Seiichiro Tarui, ${ }^{*}$ Norio Kono, * and Yuji Matsuzawa * \\ * Second Department of Internal Medicine, Osaka University Medical School, Osaka 565, Japan; and ${ }^{\ddagger}$ Otemae Hospital, Osaka 540, Japan
}

\section{Abstract}

We examined pancreas biopsy specimens from 18 newly diagnosed insulin-dependent diabetes mellitus (IDDM) patients to elucidate the mechanism underlying beta cell destruction. Pancreas islets were seen in all patients and insulitis in eight patients. Infiltrating mononuclear cells consisted of $\mathrm{CD4}^{+} \mathrm{T}$, $\mathrm{CD8}^{+} \mathrm{T}$, B lymphocytes, and macrophages. Among them, $\mathrm{CD8}^{+} \mathrm{T}$ lymphocytes were predominant and macrophages followed. The expression of MHC class I antigens was increased in islet and endothelial cells in nine patients. MHC class II expression was increased in endothelial cells of the same patients. The expression of intercellular adhesion molecule-1 was increased in endothelial cells in two of the nine patients with MHC hyperexpression; in one of them, lymphocyte functionassociated antigen-3 expression was also increased. Out of the eight patients with insulitis, seven showed MHC class I hyperexpression, whereas 2 of the 10 patients without insulitis showed the phenomenon $(P<0.05)$. The relation between insulitis and the hyperexpression of adhesion molecules was not evident. In conclusion, we revealed the close relation between $\mathrm{CD8}^{+} \mathrm{T}$ lymphocyte-predominant insulitis and MHC class I hyperexpression in islet cells. This suggests that infiltrating $\mathrm{CD8}^{+} \mathrm{T}$ lymphocytes recognize islet autoantigens in association with increased MHC class I molecules and act as major effector cells in autoimmune response against islet cells in IDDM pancreases. The role of adhesion molecules in the pathogenesis of IDDM still remains to be elucidated. (J. Clin. Invest. 1993. 92:2313-2322.) Key words: autoimmunity • immunohistochemistry • immunophenotyping • T lymphocytes • macrophages

\section{Introduction}

Mononuclear cell infiltration into the islet (insulitis) is a morphological characteristic of the pancreases of recent-onset insulin-dependent diabetes mellitus (IDDM) ${ }^{1}(1-4)$. Aberrant or

Address correspondence to Naoto Itoh, M.D., Second Department of Internal Medicine, Osaka University Medical School, 2-2 Yamadaoka, Suita, Osaka 565, Japan. 1993

Received for publication 15 March 1993 and in revised form 1 June

1. Abbreviations used in this paper: $\mathrm{H}-\mathrm{E}$, hematoxylin-eosin; ICA, islet cell antibodies; ICAM-1, intercellular adhesion molecule-1; IDDM,

J. Clin. Invest.

(C) The American Society for Clinical Investigation, Inc.

$0021-9738 / 93 / 11 / 2313 / 10 \quad \$ 2.00$

Volume 92, November 1993, 2313-2322 hyperexpression of $\mathrm{MHC}$ antigens in islet cells and endothelial cells have also been demonstrated in IDDM pancreases (4-7). Although these two phenomena suggest that immunological mechanisms participate in the process of beta cell destruction, the full elucidation for the role of the two phenomena needs further investigation. Since $\mathrm{CD} 8^{+} \mathrm{T}$ and $\mathrm{CD} 4^{+} \mathrm{T}$ lymphocytes can effectively interact with target antigens only when they are presented on cell surface in association with self-MHC class I and class II molecules, respectively (8), it is important to know what kind of cells infiltrate and how infiltrating cells are related to MHC expression.

In addition, it is interesting to investigate the expression of adhesion molecules, intercellular adhesion molecule-1 (ICAM-1), and lymphocyte function-associated antigen-3 (LFA-3). These molecules have recently been shown to play a crucial role in both cell-cell adhesion and activation in immune response (9, 10). ICAM-1 can be expressed on a wide variety of cells in response to inflammatory cytokines and bind to lymphocytes and monocytes through their cell surface LFA-1. LFA-3 is ubiquitously distributed and binds to $\mathrm{CD} 2$ on T lymphocytes. Although the ICAM-1/LFA-1 and LFA-3/CD2 interactions might participate in the process of beta cell destruction, there has been no systematized study on the expression of adhesion molecules in IDDM pancreases.

We have reported that pancreas biopsy under laparoscopy is a safe procedure to obtain pancreas tissues from newly diagnosed IDDM patients who survived acute metabolic disorders (7). This procedure has the advantage in dissecting ongoing immunopathological events in pancreases and correlating revealed immunopathological findings to the clinical aspects of patients, as compared with other autopsy studies (1-6). Using pancreas biopsy specimens from newly diagnosed IDDM patients, we examined mononuclear cell infiltration into the islet, the phenotype of infiltrating cells and the expression of cell surface molecules, MHC antigens, ICAM-1, and LFA-3 to address above mentioned issues and elucidate the mechanism underlying the beta cell destruction in IDDM. We also analyzed the relation between these findings and the clinical characteristics of the patients.

\section{Methods}

Subjects. 18 newly diagnosed IDDM patients ( 11 men and 7 women) were examined ( Table I). All patients fulfilled the criteria of National Diabetes Data Group for IDDM (11). 15 of the patients had shown

insulin-dependent diabetes mellitus; IFL, immunofluorescence, LFA3 , lymphocyte function-associated antigen-3; NOD, nonobese diabetic. 


\begin{tabular}{|c|c|c|c|c|c|c|c|}
\hline \multirow[b]{2}{*}{ Case } & \multirow[b]{2}{*}{ Age } & \multirow[b]{2}{*}{ Sex } & \multirow[b]{2}{*}{ Duration } & \multirow{2}{*}{$\begin{array}{c}\text { Urinary } \\
\text { CPR }\end{array}$} & \multirow{2}{*}{$\begin{array}{c}\text { ICA } \\
\text { JDF U }\end{array}$} & \multicolumn{2}{|c|}{ HLA } \\
\hline & & & & & & DR & DQ \\
\hline & & & mo & $\mu g / d$ & & & \\
\hline 1 & 33 & $\mathbf{M}$ & 4 & $6-15$ & 160 & $4 / 8$ & $1 / 4$ \\
\hline 2 & 29 & $\mathbf{F}$ & 4 & $13-24$ & 160 & $4 / 9$ & $3 /-$ \\
\hline 3 & 25 & $F$ & 3 & $19-27$ & 40 & $4 / 6$ & $1 / 3$ \\
\hline 4 & 26 & $\mathbf{M}$ & 4 & $7-19$ & 160 & $4 / 9$ & $3 /-$ \\
\hline 5 & 42 & $\mathbf{M}$ & 3 & $1-4$ & $<5$ & $4 / 14$ & $1 / 3$ \\
\hline 6 & 49 & $\mathbf{F}$ & 2 & $13-21$ & 40 & $4 /-$ & $3 /-$ \\
\hline 7 & 24 & $\mathbf{M}$ & 3 & $8-27$ & $<5$ & $4 /-$ & $3 /-$ \\
\hline 8 & 18 & $\mathbf{M}$ & 5 & $27-35$ & 5 & $4 /-$ & $3 /-$ \\
\hline 9 & 25 & $\mathbf{M}$ & 2 & $6-23$ & 80 & $4 / 9$ & $3 /-$ \\
\hline 10 & 24 & $\mathbf{M}$ & 2 & $7-14$ & $<5$ & $2 / 6$ & $1 / 3$ \\
\hline 11 & 40 & $\mathbf{F}$ & 0 & $10-27$ & 5 & $6 / 9$ & $1 / 3$ \\
\hline 12 & 53 & $\mathbf{F}$ & 1 & $6-26$ & 320 & $9 / 10$ & $1 / 3$ \\
\hline 13 & 26 & $\mathbf{M}$ & 1 & $5-19$ & $<5$ & $4 / 6$ & $1 /-$ \\
\hline 14 & 24 & $\mathrm{~F}$ & 6 & $14-36$ & 5 & $4 /-$ & $-1-$ \\
\hline 15 & 17 & $\mathbf{M}$ & 3 & $18-47$ & $<5$ & $6 / 9$ & $1 / 3$ \\
\hline 16 & 42 & $\mathbf{M}$ & 5 & $1-3$ & $<5$ & $4 / 9$ & $3 /-$ \\
\hline 17 & 22 & $\mathbf{F}$ & 4 & $4-15$ & 640 & $4 / 9$ & $3 / 4$ \\
\hline 18 & 34 & $\mathbf{M}$ & 7 & $5-19$ & 320 & 9/- & $3 /-$ \\
\hline
\end{tabular}

CPR, C-peptide immunoreactivity; JDF, juvenile diabetes foundation.

typical abrupt onset of diabetes with ketosis. In the other three (cases 9, 11 , and 12 ), the disease had progressed more slowly to the insulin-dependent state: it took $42.3 \pm 21.8$ mo (mean $\pm S D$ ) from the first detection of non-insulin-dependent hyperglycemic state to the beginning of insulin-dependent state, the clinical course of which was considered that of slowly progressive IDDM (12). In these three patients, onset of IDDM was assumed when insulin injection was required to prevent ketosis. The average age of the 18 patients was $30.7 \pm 10.5 \mathrm{yr}$, (mean \pm SD) and the duration from clinical onset of IDDM was $3.3 \pm 1.8$ mo. Islet cell antibodies (ICA) were detected in 12 of 18 patients by an indirect immunofluorescence (IFL) method (13).

Pancreas specimens. The study protocol described below was approved by the ethical committee of Osaka University Medical School and was carried out in accordance with the Declaration of Helsinki. The purpose of the study was to closely examine IDDM pancreases as soon as possible after disease onset to elucidate the pathogenesis of IDDM. The method of pancreas biopsy was previously described (7). Briefly, a laparoscope was inserted into the abdominal cavity under local anesthesia. After direct inspection of the pancreas, a piece of tissue was obtained from the body of the pancreas with a biopsy forceps. Special attention was paid not to injury any visible vessels during biopsy and to confirm clotting at the biopsy site after biopsy. Possible complications were allergic reaction, pancreatitis, peritonitis, bleeding, and so on. We explained the purpose, method, risks, and the freedom of consent to the patients and their families, and obtained written informed consent from all of them. In all patients, pancreas biopsies were performed without any complications.

Half of biopsy tissues were immediately frozen in dry ice acetone and isopentane and $5 \mu \mathrm{m}$-thick sections were cut on a cryostat. About 300 consecutive sections were made from each biopsy tissue and stored at $-80^{\circ} \mathrm{C}$ until used. Every 11 th cryostat section was stained with hematoxylin-eosin (H-E) and histologically examined by light microscopy. Remaining cryostat sections were used for immunohistochemical study. Control pancreas tissues were obtained from normal parts of the pancreas body of five subjects (three men and two women) who underwent partial pancreatectomy for gastric cancer. The age of the control subjects was $54.6 \pm 8.3 \mathrm{yr}$ (mean $\pm \mathrm{SD}$ ), and the glucose tolerance of these subjects was within normal range before the operation. Control tissues were prepared in the same manner as the biopsy specimens.

Immunohistochemistry. An indirect IFL method was used to detect mononuclear cell infiltration into the islet and to examine the expression of MHC antigens and adhesion molecules in the pancreas. Sections were air dried for $30 \mathrm{~min}$, prefixed in cold acetone for $10 \mathrm{~min}$, and

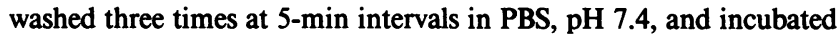
overnight at $4^{\circ} \mathrm{C}$ with one of the following antibodies: monoclonal mouse anti-T lymphocytes CD3 (T3-4B5; Dakopatts, Glostrup, Denmark), CD4 (MT310; Dakopatts), CD8 (DK25; Dakopatts), B lymphocytes(L26; Dakopatts), macrophages (EBM11; Dakopatts), MHC class I antigens (W6/32; Serotec, Oxford, England), MHC class II antigens (L243, Becton-Dickinson, Mountain View, CA), ICAM-1 (84H10; Immunotech, Marseille, France), and LFA-3 (TS2/9 kindly provided by Dr. T. A. Springer, Dana-Farber Cancer Institute, Boston, MA) (14). After washing in PBS, the sections were incubated for 60 min at room temperature with biotinylated horse anti-mouse immunoglobulins (Vector Laboratories, Burlingame, CA ) and then for an additional 30 min with FITC-conjugated avidin (Vector Laboratories). The section was washed in PBS, mounted with glycerin, and evaluated in a fluorescence microscope with epiillumination (Olympus, Tokyo, Japan).

A double IFL method was used to examine the relation between mononuclear cells and the islet; in this method, the above mentioned procedure was followed by an incubation with guinea pig antiinsulin (Dakopatts) or rabbit antiglucagon (kindly provided by Dr. S. Iwasa, Takeda Chemical, Osaka, Japan) antibody and the corresponding secondary antibody, rhodamine-conjugated rabbit anti-guinea pig (Zymed Laboratories, Inc., South San Francisco, CA) or Texas redconjugated donkey anti-rabbit (Amersham International, Amersham, United Kingdom) immunoglobulins. A double IFL method was also used to determine the relation between MHC antigens, adhesion molecules and endothelial cells; in this method, the primary monoclonal antibody was followed by rhodamine-conjugated avidin (Vector Labo- 

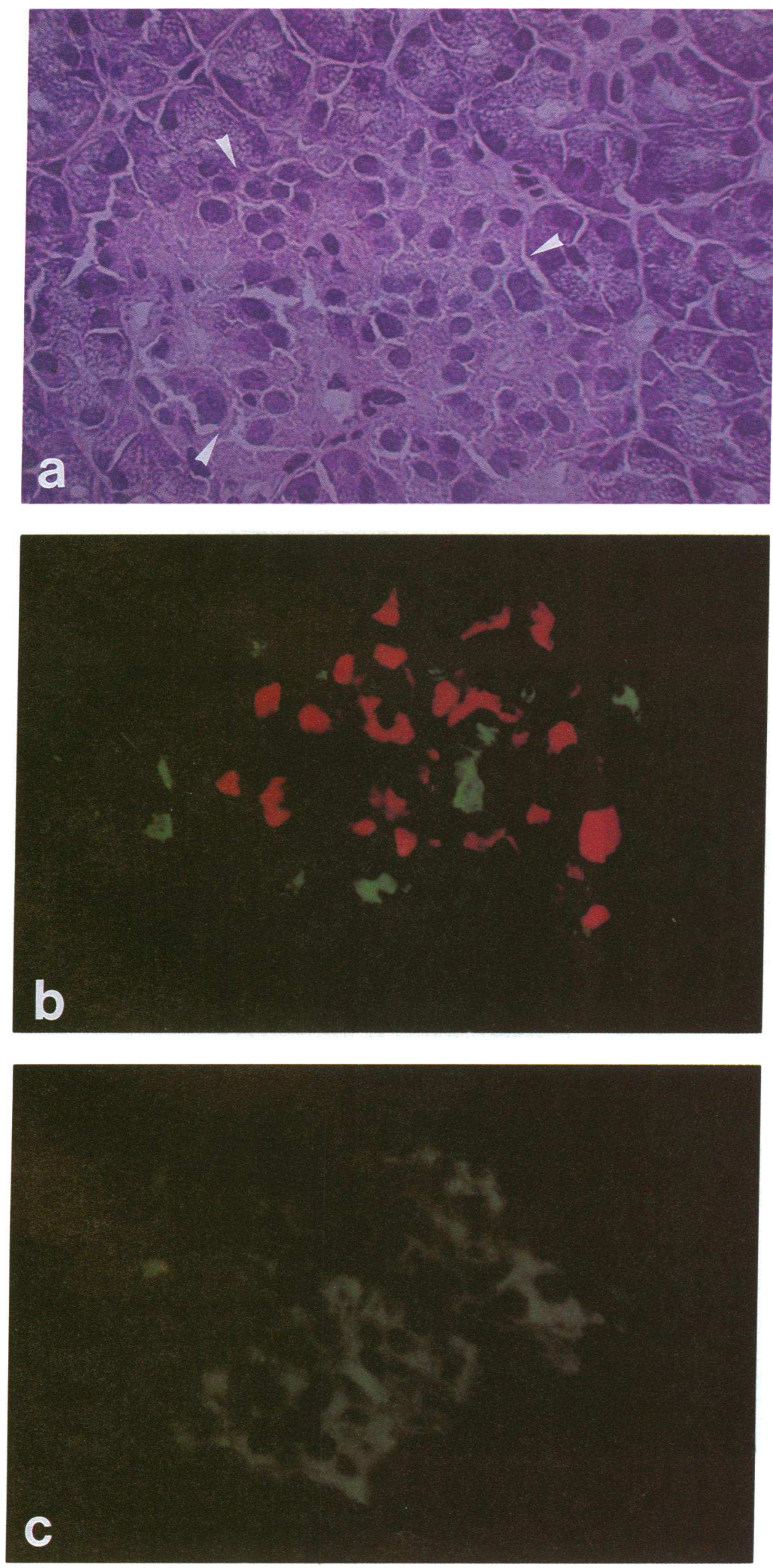

Figure 1. Consecutive pancreas sections of case 13 stained with $(a) \mathrm{H}-\mathrm{E},(b)$ antiglucagon (red) and anti-CD3 ${ }^{+} \mathrm{T}$ lymphocytes (green), and (c) antiinsulin. An islet is slightly atrophic and distorted (arrowheads). Insulitis is not evident by light microscopy $(a ; \times 400)$, but detected by the double immunofluorescence method $(b ; \times 400)$. Several $\mathrm{CD}^{+} \mathrm{T}$ lymphocytes infiltrate the remaining islet cells. Insulin content is reduced in the islet $(c ; \times 400)$. 
ratories), sheep anti-Factor VIII antibody (Serotec), and FITC-conjugated donkey anti-sheep immunoglobulins (Serotec).

Statistical analysis. The significance between two groups was evaluated by Fisher's exact test.

\section{Results}

Mononuclear cell infiltration into the islet (insulitis). Pancreas islets were detected in all patients on light microscopic examina- tion of H-E staining sections. Most of these islets were small, atrophic, and distorted as compared with islets in normal pancreases. Mononuclear cell infiltration into the islet was hardly seen in any IDDM pancreas sections stained with H-E. However, sparse mononuclear cell infiltration into the islet (insulitis) was demonstrated by the IFL method (Fig. 1). Insulitis was most evidently demonstrated when the combination of diverse monoclonal antibodies to mononuclear cells and antiglucagon
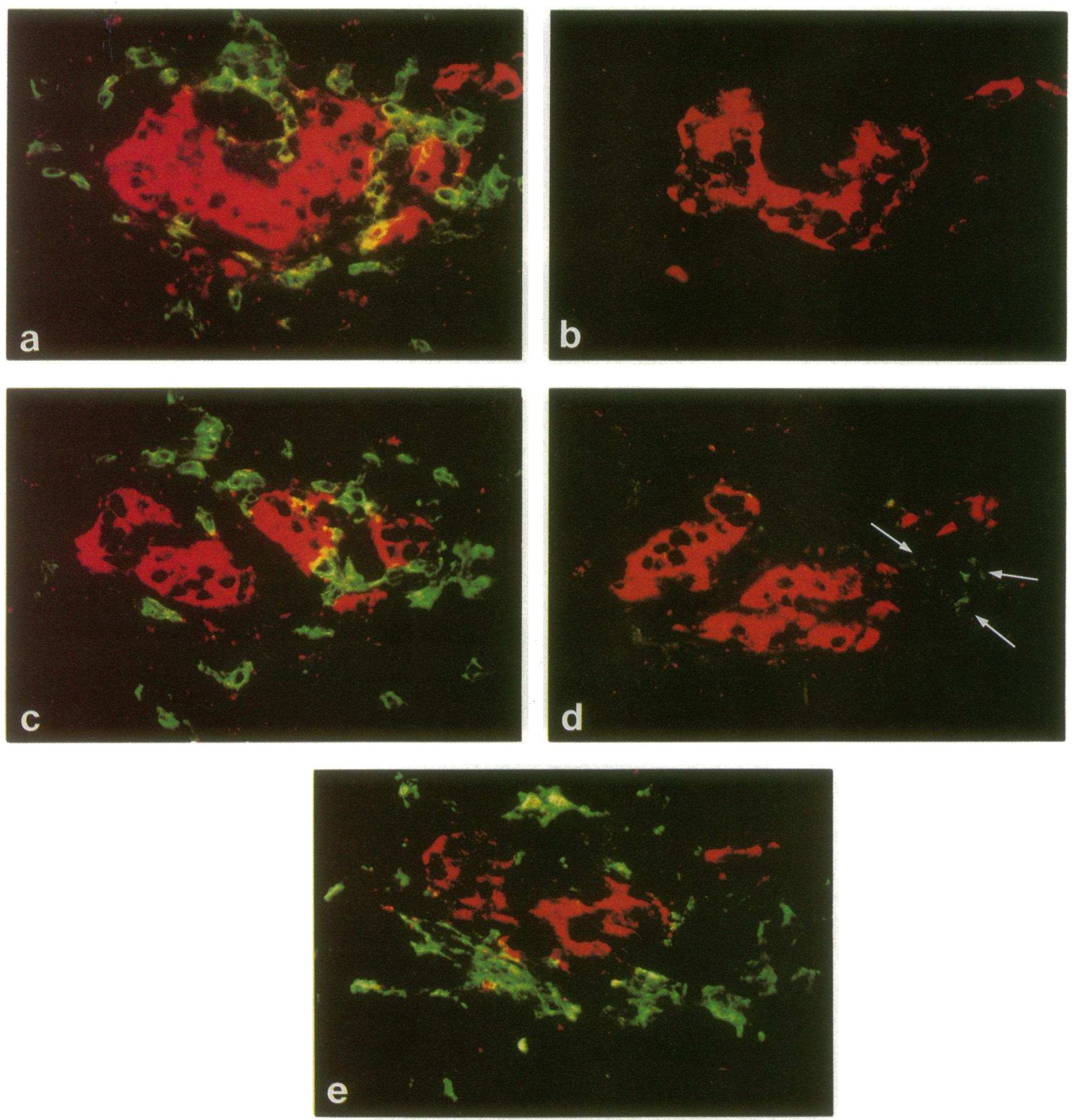

Figure 2. Phenotypic analysis of infiltrating cells (green) in the islet of consecutive sections of case $17(a-e)$. Staining with monoclonal antibodies to $\mathrm{CD}^{+} \mathrm{T}$ lymphocytes $(a ; \times 400), \mathrm{CD} 4^{+} \mathrm{T}$ lymphocytes $(b ; \times 400), \mathrm{CD}^{+} \mathrm{T}$ lymphocytes $(c ; \times 400), \mathrm{B}$ lymphocytes $(d$, arrows; $\times 400)$, and macrophages $(e ; \times 400) . \mathrm{CD}^{+} \mathrm{T}$ lymphocytes are predominant and macrophages follow. $\mathrm{CD}^{+} \mathrm{T}$ lymphocyte is not seen in this islet. Antiglucagon staining (red) is used to outline a residual islet. 
Table II. Immunohistochemical Analysis of the Pancreas with Monoclonal Antibody to Mononuclear Cells

\begin{tabular}{|c|c|c|c|c|c|c|c|c|c|}
\hline \multirow[b]{2}{*}{ Case } & \multirow{2}{*}{$\begin{array}{c}\text { Number of } \\
\text { islets } \\
\text { per one } \\
\text { section }\end{array}$} & \multicolumn{5}{|c|}{$\begin{array}{c}\text { Number of islets with insulitis/ } \\
\text { number of islets examined with antibody to }\end{array}$} & \multirow{2}{*}{$\begin{array}{l}\text { Total number of } \\
\text { islets with } \\
\text { insulitis (I) }\end{array}$} & \multirow{2}{*}{$\begin{array}{l}\text { Total number } \\
\text { of islets } \\
\text { examined } \\
\text { (T) }\end{array}$} & \multirow{2}{*}{$\begin{array}{l}\mathrm{I} / \mathrm{T} \\
(\%)\end{array}$} \\
\hline & & CD3 & CD4 & CD8 & B & $\mathbf{M} \phi$ & & & \\
\hline \multicolumn{10}{|c|}{ IDDM } \\
\hline 1 & 9 & $3 / 9$ & ND & ND & ND & ND & 3 & 9 & 33.3 \\
\hline 2 & 2 & $0 / 4$ & $0 / 2$ & $0 / 2$ & $0 / 2$ & $0 / 2$ & 0 & 12 & 0 \\
\hline 3 & $2-7$ & $0 / 9$ & $0 / 2$ & $0 / 2$ & $0 / 2$ & $0 / 2$ & 0 & 17 & 0 \\
\hline 4 & $0-2$ & $0 / 4$ & $0 / 1$ & $0 / 1$ & $0 / 2$ & $0 / 3$ & 0 & 11 & 0 \\
\hline 5 & $2-13$ & $0 / 17$ & $0 / 2$ & $0 / 2$ & $0 / 2$ & $0 / 2$ & 0 & 25 & 0 \\
\hline 6 & $2-6$ & $2 / 13$ & $2 / 11$ & $2 / 11$ & $0 / 11$ & $2 / 13$ & 8 & 59 & 13.6 \\
\hline 7 & $3-7$ & $0 / 24$ & $0 / 21$ & $0 / 18$ & $0 / 16$ & $0 / 19$ & 0 & 98 & 0 \\
\hline 8 & $2-7$ & $0 / 15$ & $0 / 8$ & $0 / 8$ & $0 / 8$ & $0 / 15$ & 0 & 54 & 0 \\
\hline 9 & $1-4$ & $0 / 12$ & $0 / 8$ & $0 / 8$ & $0 / 8$ & $0 / 12$ & 0 & 48 & 0 \\
\hline 10 & $2-13$ & $7 / 52$ & $0 / 33$ & $3 / 33$ & $3 / 38$ & $7 / 36$ & 20 & 192 & 10.4 \\
\hline 11 & $3-6$ & $0 / 21$ & $0 / 6$ & $0 / 6$ & $0 / 3$ & $0 / 11$ & 0 & 47 & 0 \\
\hline 12 & $0-4$ & $0 / 14$ & $0 / 4$ & $0 / 4$ & $0 / 3$ & $0 / 9$ & 0 & 34 & 0 \\
\hline 13 & $1-9$ & $11 / 53$ & $1 / 30$ & $9 / 31$ & $1 / 29$ & $2 / 23$ & 24 & 166 & 14.5 \\
\hline 14 & $1-6$ & $3 / 28$ & $0 / 24$ & $3 / 25$ & $1 / 25$ & $2 / 23$ & 9 & 125 & 7.2 \\
\hline 15 & $4-8$ & $0 / 27$ & $0 / 26$ & $0 / 26$ & $0 / 24$ & $0 / 27$ & 0 & 130 & 0 \\
\hline 16 & $9-12$ & $0 / 57$ & $0 / 45$ & $0 / 45$ & $0 / 45$ & $0 / 35$ & 0 & 227 & 0 \\
\hline 17 & $1-9$ & $9 / 21$ & $2 / 15$ & $5 / 15$ & $1 / 15$ & $4 / 15$ & 21 & 81 & 25.9 \\
\hline 18 & $6-21$ & $6 / 144$ & $0 / 48$ & $3 / 52$ & $0 / 47$ & $2 / 49$ & 11 & 340 & 3.2 \\
\hline \multicolumn{10}{|c|}{ Control } \\
\hline 1 & $21-23$ & $0 / 156$ & $0 / 75$ & $0 / 79$ & $0 / 105$ & $0 / 77$ & 0 & 492 & 0 \\
\hline 2 & $10-54$ & $0 / 102$ & $0 / 27$ & $0 / 26$ & $0 / 61$ & $0 / 48$ & 0 & 264 & 0 \\
\hline 3 & $26-68$ & $1 / 272$ & $0 / 184$ & $0 / 190$ & $0 / 181$ & $0 / 183$ & 1 & 1010 & 0.1 \\
\hline 4 & $18-39$ & $1 / 137$ & $0 / 60$ & $0 / 60$ & $0 / 72$ & $1 / 92$ & 2 & 421 & 0.5 \\
\hline 5 & $16-43$ & $0 / 227$ & $0 / 73$ & $0 / 79$ & $0 / 109$ & $0 / 96$ & 0 & 584 & 0 \\
\hline
\end{tabular}

CD3, $\mathrm{CD}^{+}{ }^{+} \mathrm{T}$ lymphocytes; CD4, CD4 ${ }^{+} \mathrm{T}$ lymphocytes; CD8, CD8 ${ }^{+} \mathrm{T}$ lymphocytes; B, B lymphocytes; M $\phi$ macrophages; ND, not determined.

antibody was used (Figs. 1 and 2). The combination with antiinsulin antibody was useless in detecting such phenomenon in many of IDDM pancreas sections, since the content of insulin was reduced to a moderate or great extent. Therefore, we used staining with antiglucagon antibody to detect insulitis by the double IFL method, and staining with antiinsulin antibody in a consecutive section to examine whether insulin remained in insulitis-positive islets. By this method, infiltration of 2-62 mononuclear cells was clearly shown in $3-33 \%$ of examined islets in seven patients ( Table II). Insulin staining was positive in most of the insulitis-positive islets (Fig. 1). Insulitis was also revealed in another patient by electron microscopy (not shown).

When only one mononuclear cell was shown in the islet, this was excluded from the diagnosis of insulitis mentioned above. Since one mononuclear cell was sometimes seen in normal islets, it was difficult to judge such findings pathologic or incidental. According to this criteria, insulitis, infiltration of two or more mononuclear cells into the islet, was hardly seen in normal pancreas sections. Out of 2,771 normal islets totally examined, only three large islets contained two to three mononuclear cells $(0.12 \pm 0.21 \%$, mean $\pm S D$, Table II $)$.

Phenotypic analysis of infiltrating mononuclear cells. Phenotype of infiltrating cells could be analyzed in 6 of 8 patients who showed insulitis. The number of infiltrating cells ranged from 2 to 62 per one islet with insulitis. These cells were composed of $\mathrm{CD}^{+} \mathrm{T}, \mathrm{CD} 4^{+} \mathrm{T}$, B lymphocytes, and macrophages
(Fig. 2). Both $\mathrm{CD}^{+} \mathrm{T}$ lymphocytes and macrophages were seen in all six patients examined, whereas B lymphocytes in four and $\mathrm{CD}^{+} \mathrm{T}$ lymphocytes in three (Tables II and III). Although the percent of each phenotype in each islet with insulitis varied from 0 to $100 \%$ (Table III), $\mathrm{CD}^{+}{ }^{+} \mathrm{T}$ lymphocytes were predominant in $\geq 50 \%$ of the insulitis-positive islets in five of the six patients. In another one patient (case 10), $43 \%$ of insulitis-positive islets were $\mathrm{CD}^{+} \mathrm{T}$ lymphocyte-predominant, and the remainder of the islets were macrophage-predominant.

Table III. Percent of Stained Cells in the Islet with Insulitis

\begin{tabular}{ccccc}
\hline & \multicolumn{4}{c}{ Subset (\%) } \\
\cline { 2 - 5 } Case & CD4 & CD8 & B & M $\phi$ \\
\hline 6 & $23-50$ & $22-46$ & 0 & $28-31$ \\
10 & 0 & $0-100$ & $0-40$ & $0-100$ \\
13 & $0-13$ & $0-100$ & $0-33$ & $0-100$ \\
14 & 0 & $50-60$ & $0-20$ & $20-50$ \\
17 & $0-14$ & $53-86$ & $0-4$ & $0-47$ \\
18 & 0 & $50-100$ & 0 & $0-50$ \\
\hline
\end{tabular}

CD4, CD4 ${ }^{+} \mathrm{T}$ lymphocytes; CD8, $\mathrm{CD}^{+} \mathrm{T}$ lymphocytes; B, B lymphocytes; $\mathrm{M} \phi$, macrophages. 
Expression of MHC antigens and adhesion molecules. In 9 of 18 patients, the expression of MHC class I antigens was increased in islet cells and endothelial cells as compared with that in normal pancreases (Fig. 3 and Table IV). The expression of MHC class II antigens was also increased in endothelial cells of the same nine patients (Table IV). In addition, the expression of ICAM-1 was increased in endothelial cells in two of nine patients who showed the hyperexpression of MHC antigens; in one of the two the expression of LFA-3 was also increased (Fig. 4 and Table IV). Neither ICAM-1 nor LFA-3 was expressed in any islet cells examined. The double IFL methods using antiinsulin, antiglucagon, and anti-Factor VIII antibodies confirmed the expression of MHC antigens on islet cells and endothelial cells, and that of adhesion molecules on endothelial cells (not shown). Although the age of control subjects is somewhat higher than that of IDDM patients, there is no dif- ference in basic immunohistochemical findings in respect of mononuclear cells in the islet and the expression of MHC antigens and adhesion molecules between the two groups.

Insulitis, MHC antigen expression, adhesion molecule expression, and clinical characteristics. Seven of the eight patients with insulitis showed the hyperexpression of MHC antigens (Table IV), whereas only 2 of the 10 patients without insulitis showed the same phenomenon $(P<0.05)$. Neither insulitis nor the hyperexpression of MHC antigens nor the hyperexpression of adhesion molecules in the pancreas was significantly related to the clinical characteristics of the patients such as age, sex, disease duration, urinary C-peptide excretion, ICA titer, and HLA typing. However, it is notable that insulitis was not seen in slowly progressive IDDM patients (case 9, 11, and 12), although autoimmune mechanism is suspected to be involved in their disease course (12). It is also remarkable that neither
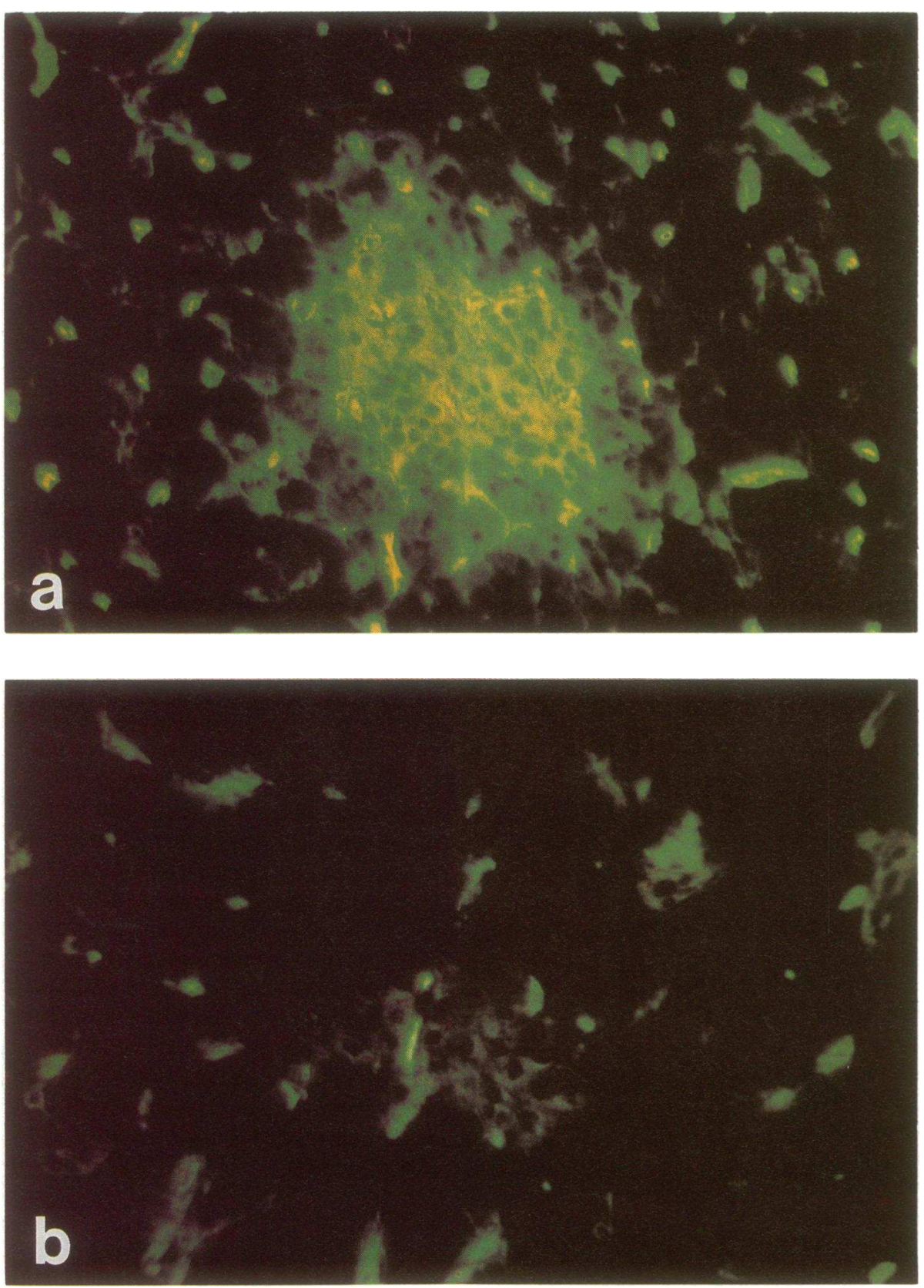

Figure 3. Expression of MHC class I antigens is increased in the same islet and endothelial cells shown in Fig. 1 $(a ; \times 200)$. Normal control pancreas shows only faint expression of MHC class I antigens in islet cells and weak one in endothelial cells $(b ; \times 200)$. 
Table IV. Immunohistochemical Findings of the Expression of MHC Antigens and Adhesion Molecules in Pancreas Biopsy Specimens and Its Relation to Insulitis

\begin{tabular}{|c|c|c|c|c|c|}
\hline \multirow[b]{2}{*}{ Case } & \multirow[b]{2}{*}{ Insulitis } & \multicolumn{4}{|c|}{$\begin{array}{l}\text { Expression of cell surface molecules } \\
\text { (in islet cells/in endothelial cells) }\end{array}$} \\
\hline & & MHC class I & MHC class II & ICAM-1 & LFA-3 \\
\hline 1 & $+^{*}$ & $+/+$ & $\mathrm{A}-, \mathrm{B}+/+$ & $\mathrm{N} / \mathrm{N}$ & $\mathrm{N} / \mathrm{N}$ \\
\hline 2 & - & $+1+$ & $\mathrm{N} /+$ & $\mathrm{N} / \mathrm{N}$ & $\mathrm{N} / \mathrm{N}$ \\
\hline 3 & - & $\mathrm{N} / \mathrm{N}$ & $\mathrm{N} / \mathrm{N}$ & $\mathrm{N} / \mathrm{N}$ & $\mathrm{N} / \mathrm{N}$ \\
\hline 4 & $+^{\ddagger}$ & $+1+$ & $\mathrm{N} /+$ & $\mathrm{N} /+$ & $\mathrm{N} /+$ \\
\hline 5 & - & $\mathrm{N} / \mathrm{N}$ & $\mathrm{N} / \mathrm{N}$ & $\mathrm{N} / \mathrm{N}$ & $\mathrm{N} / \mathrm{N}$ \\
\hline 6 & $+^{*}$ & $+1+$ & $\mathrm{N} /+$ & $\mathrm{N} / \mathrm{N}$ & $\mathrm{N} / \mathrm{N}$ \\
\hline 7 & - & $\mathrm{N} / \mathrm{N}$ & $\mathrm{N} / \mathrm{N}$ & $\mathrm{N} / \mathrm{N}$ & $\mathrm{N} / \mathrm{N}$ \\
\hline 8 & - & $\mathrm{N} / \mathrm{N}$ & $\mathrm{N} / \mathrm{N}$ & $\mathrm{N} / \mathrm{N}$ & $\mathrm{N} / \mathrm{N}$ \\
\hline 9 & - & $+1+$ & $\mathrm{N} /+$ & $\mathrm{N} /+$ & $\mathrm{N} / \mathrm{N}$ \\
\hline 10 & $+^{*}$ & $+/+$ & $\mathrm{N} /+$ & $\mathrm{N} / \mathrm{N}$ & $\mathrm{N} / \mathrm{N}$ \\
\hline 11 & - & $\mathrm{N} / \mathrm{N}$ & $\mathrm{N} / \mathrm{N}$ & $\mathrm{N} / \mathrm{N}$ & $\mathrm{N} / \mathrm{N}$ \\
\hline 12 & - & $\mathrm{N} / \mathrm{N}$ & $\mathrm{N} / \mathrm{N}$ & $\mathrm{N} / \mathrm{N}$ & $\mathrm{N} / \mathrm{N}$ \\
\hline 13 & $t^{*}$ & $+1+$ & $\mathrm{N} /+$ & $\mathrm{N} / \mathrm{N}$ & $\mathrm{N} / \mathrm{N}$ \\
\hline 14 & $+^{*}$ & $+1+$ & $\mathrm{N} /+$ & $\mathrm{N} / \mathrm{N}$ & $\mathrm{N} / \mathrm{N}$ \\
\hline 15 & - & $\mathrm{N} / \mathrm{N}$ & $\mathrm{N} / \mathrm{N}$ & $\mathrm{N} / \mathrm{N}$ & $\mathrm{N} / \mathrm{N}$ \\
\hline 16 & - & $\mathrm{N} / \mathrm{N}$ & $\mathrm{N} / \mathrm{N}$ & $\mathrm{N} / \mathrm{N}$ & $\mathrm{N} / \mathrm{N}$ \\
\hline 17 & $t^{*}$ & $+/+$ & $\mathrm{N} /+$ & $\mathrm{N} / \mathrm{N}$ & $\mathrm{N} / \mathrm{N}$ \\
\hline 18 & $+^{*}$ & $\mathrm{~N} / \mathrm{N}$ & $\mathrm{N} / \mathrm{N}$ & $\mathrm{N} / \mathrm{N}$ & $\mathrm{N} / \mathrm{N}$ \\
\hline $\begin{array}{l}\text { Control } \\
\qquad(n=5)\end{array}$ & - & $\pm /+$ & $-/ \pm$ & $-/ \pm$ & $-/ \pm$ \\
\hline
\end{tabular}

* Immunohistochemical finding; ${ }^{*}$ electron microscopic finding. A, alpha cells; B, beta cells. ${ }^{8}$ Scoring system for cell surface molecules expression (IDDM patients): + , hyperexpression or aberrant expression; $\mathrm{N}$, normal expression. Control subjects - , negative; \pm , weakly positive; + , positive.

insulitis nor ICA was detected in patients whose urinary C-peptide excretion is markedly decreased, $<5 \mu \mathrm{g} / \mathrm{d}$ (case 5 and 16 ), despite the short duration from disease onset.

\section{Discussion}

We revealed mononuclear cell infiltration into the islet in newly diagnosed IDDM patients who survived acute metabolic disorders. The use of better antibodies coupled with an avidinbiotin system enabled us to detect insulitis even in the cases in which insulitis had not been observed in our earlier examination (7). However, both of the number of infiltrating cells and the proportion of patients with insulitis seemed to be fewer than that observed in autopsy studies reported in Europe (14). Several possible explanations exist for this difference. The severity of metabolic disorders might affect the function of mononuclear cells and subsequently immune response against beta cells. The age of the patients might be related to the degree of immune response. Since the frequency of insulitis was reported to be high in recent-onset IDDM patients under $15 \mathrm{yr}$ of age (3), the higher age of the patients in our study could explain the difference in the frequency and the degree of insulitis. Racial difference also has to be considered. Since HLA types susceptible to IDDM in Japanese are different from those in Caucasians (15), immune response against beta cell autoantigens might be different between the two ethnic groups. The time of biopsy is another important factor. Although the time of biopsy was only $3 \mathrm{mo}$ on an average after clinical onset of IDDM, the fact that the volume of beta cells was markedly decreased to less than one fifth of that in control subjects in newly diagnosed patients (16) suggests that the cell-mediated immune response is already in a late stage. Finally, we have to consider a sampling problem. Autopsy studies on the whole pancreas indicated the heterogeneous distribution of the pathological region $(3,5,6)$. Considering this issue, we have always taken biopsy samples from the same position of the pancreas (7) to decrease variation among the patients. In addition, we have always examined sections from several different parts of the biopsy tissue.

We analyzed the composition of mononuclear cells infiltrating into the islet by the double IFL method using diverse monoclonal antibodies. $\mathrm{CD} 8{ }^{+} \mathrm{T}$ lymphocytes were the predominant subpopulation and macrophages followed. Fewer $\mathrm{CD}^{+} \mathrm{T}$ and $\mathrm{B}$ lymphocytes were also seen. This composition of infiltrating cells was comparable with that observed in a previous autopsy case (4) and pancreas-transplanted cases (17, 18 ). Very recent pathological study on the autopsy pancreas at the onset of IDDM (19) also gave the same finding. To date, all the cases in which phenotypic analyses of infiltrating cells could be performed $(4,17-19)$ subsequently showed that $\mathrm{CD}^{+} \mathrm{T}$ lymphocytes were the predominant subpopulation. $\mathrm{CD}^{+} \mathrm{T}$ lymphocytes recognize target antigens in conjunction with self MHC class I molecules and act as the chief effector in cellular immunity. We found that seven out of the eight pancreases with insulitis showed the hyperexpression of MHC class $\mathrm{I}$ antigens in islet cells. Taken together, infiltrating CD8 ${ }^{+} \mathrm{T}$ lymphocytes might be cytotoxic effector cells recognizing beta cell autoantigens. The crucial role of $\mathrm{CD} 8^{+} \mathrm{T}$ lymphocytes in the pathogenesis of IDDM is also supported by the findings in animal models, nonobese diabetic (NOD) mice (20-24). CD8 

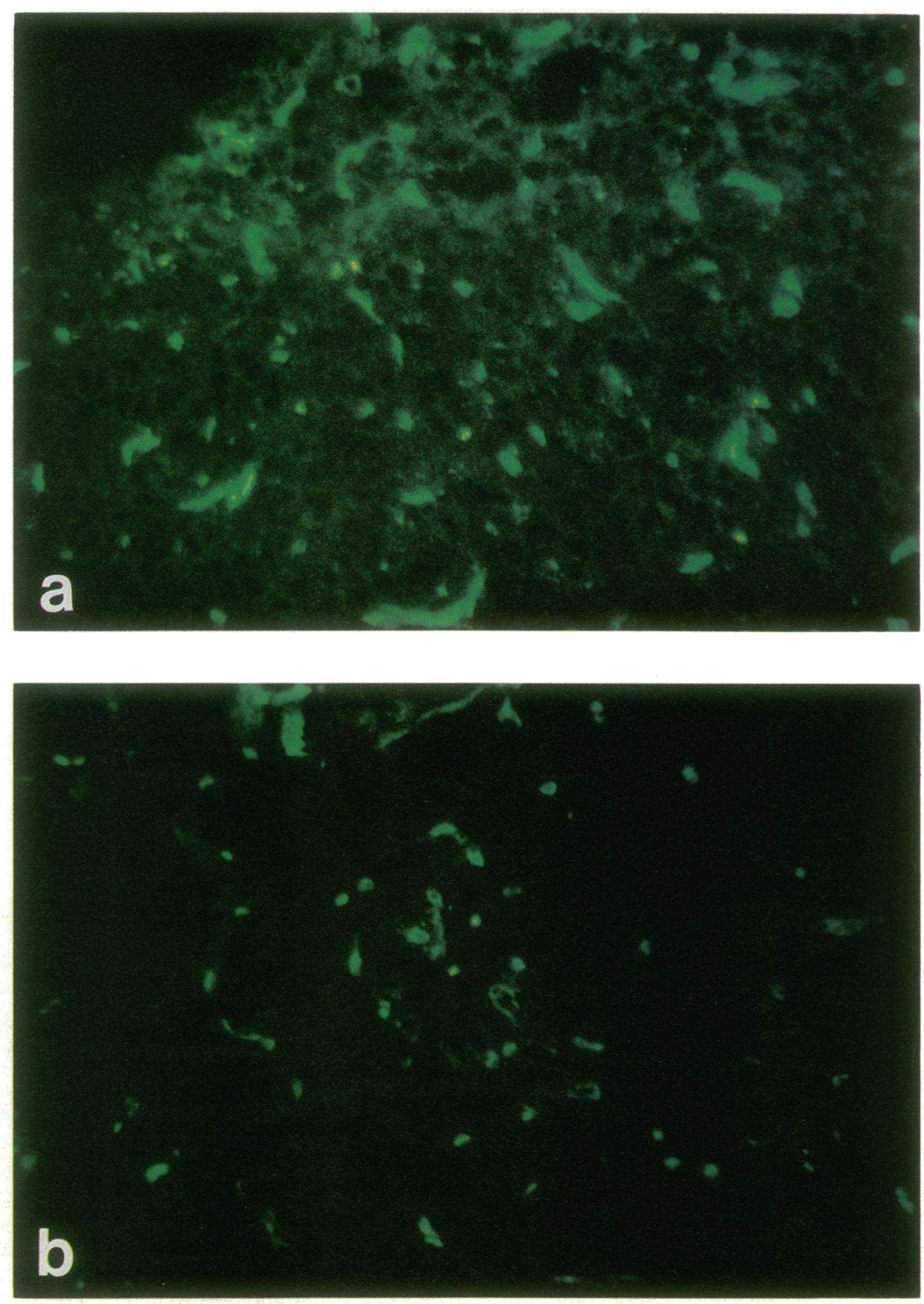

Figure 4. Expression of ICAM-1 is increased in endothelial cells in type 1 diabetic pancreas (case $9, a ; \times 200$ ) as compared with that in normal pancreas $(b ; \times 200)$.
(Lyt-2) ${ }^{+}$lymphocytes are required to successfully transfer diabetes into recipient NOD mice as well as CD4 (L3T4) ${ }^{+}$ lymphocytes (20-23). Morphological analysis showed the direct contact of CD8 (Lyt- $)^{+}$islet-associated mononuclear cells with pancreatic beta cells and the rapid cytolysis of beta cells (23).

Macrophages, $\mathrm{CD}^{+} \mathrm{T}$ and $\mathrm{B}$ lymphocytes are other subpopulations observed in the islet in our series. Although the crucial role of macrophages in the pathogenesis of IDDM is recognized by the fact that the impairment of macrophage function prevents diabetes in animal models (24-26), it remains to be elucidated in humans. We and others $(19,29)$ showed that some parts of infiltrating cells were certainly macrophages. It is conceivable that macrophages participate in the process of beta cell destruction by initiating immune response as antigen-presenting cells, by producing cytokines or by phago- cytosis of damaged beta cells. $\mathrm{CD}^{+}$lymphocytes are other candidates for effectors in autoimmune beta cell destruction (27). $\mathrm{CD}^{+} \mathrm{T}$ lymphocytes might act as helper cells in autoimmune response against beta cells. Sequential studies of the pancreas of $\mathrm{T}$ cell-transferred NOD mice demonstrated that CD4 (L3T4 $)^{+}$lymphocytes predominated at an early phase of insulitis and CD8 (Lyt-2) ${ }^{+}$lymphocytes increased at a later stage (28). However, it has not been clear what mononuclear cells are major constituent of infiltrating cells at an initial stage of insulitis in human, since human pancreases could not be analyzed in prediabetic period. $\mathrm{CD}^{+}$lymphocytes are possibly predominant from the early phase of insulitis in human IDDM as seen in our study. This is supported by the finding that $C D 8^{+}$ lymphocytes were already main infiltrating cells into islets of grafted pancreas when beta cells were relatively preserved and diabetes had not recurred (17). 
We found the close relation between insulitis and MHC class I antigen hyperexpression as mentioned. There has been controversy as to which is the first event $(6,29)$, and it could not be clarified even in our study. If the hyperexpression of MHC class I antigens occurs first, it would elicit autoreactive T lymphocyte infiltration, and if the converse is the case, infiltrating lymphocytes would provoke cytokine production resulting in the hyperexpression of MHC class I antigens in islet cells (30). Irrespective of the order, both of these phenomena seem to accelerate the cascade of autoimmune response in IDDM pancreases.

In relation to these phenomena, it is interesting to determine whether cytokines are expressed in islet cells or infiltrating mononuclear cells as reported by Foulis et al. $(31,32)$, since cytokines are important factors in enhancing autoimmune response. Therefore, we examined the expression of IFN- $\alpha$, IFN- $\gamma$, IL- 1 and IL-6, but could not find the expression of these cytokines in any cells of IDDM pancreases (unpublished observation). This might be caused by the poor sensitivity of used antibodies and could be clarified by more sensitive methods such as in situ hybridization.

Adhesion molecules are essential in cell-cell interactions in immune response $(9,10)$ and their role in autoimmune diseases has been indicated (33-35). Previous experimental studies $(36,37)$ demonstrated that pancreatic islet cells could express adhesion molecules, as well as MHC molecules, when stimulated by IFN- $\gamma$ and/or TNF- $\alpha$ in vitro, suggesting the possible participation of the molecules in the pathogenesis of IDDM. Therefore, we analyzed two adhesion molecules, ICAM-1 and LFA-3, in IDDM pancreases. The expression of adhesion molecules could not be detected in islet cells. The hyperexpression of ICAM-1 in endothelial cells was found in two patients and that of LFA-3 in one of the two patients. This hyperexpression of adhesion molecules in endothelial cells is compatible with the recent case report of autopsy IDDM pancreas (19). Since the number of patients with such phenomena is still small, it is difficult to discuss the role of adhesion molecules in the pathogenesis of IDDM. However, hyperexpressed adhesion molecules might help lymphocytes cross endothelial and basement membrane barriers and congregate in the islet in some IDDM patients.

In conclusion, we revealed that insulitis is predominantly composed of $\mathrm{CD}^{+} \mathrm{T}$ lymphocytes and that there is a close relationship between $\mathrm{CD} 8^{+} \mathrm{T}$ lymphocyte-predominant insulitis and MHC class I antigen hyperexpression in islet cells in the pancreas biopsy specimens from newly diagnosed IDDM patients. This suggests that $\mathrm{CD} 8^{+} \mathrm{T}$ lymphocytes play a significant role in the pathogenesis of IDDM via the recognition of autoantigens in association with hyperexpressed MHC class I molecules. Although the hyperexpression of adhesion molecules was observed in two patients, its role in immune response in IDDM still remains to be elucidated. Our findings might not reflect the very first events of the disease. However, these results could not be elicited from other studies using animal models or human autopsies.

\section{Acknowledgments}

We would like to thank Drs. Timothy A. Springer and Susumu Iwasa for the generous gifts of the antibodies and Drs. Morito Monden and Hitoshi Shiozaki for providing normal pancreases. Drs. Kyoichi Hasegawa, Hiroyuki Toyoshima, Susumu Misugi, Mamiko Tsugawa, Aki- hito Otsuka, Hayato Katsura, and Chisa Nakagawa kindly referred IDDM patients to Second Department of Internal Medicine, Osaka University Medical School. We also wish to thank Drs. Yoshitake Shinji and Kentaro Yamada for their kind help in facilitating this research. This study was supported in part by the Scientific Research Fund from the Ministry of Education, Science and Culture of Japan, a grant for diabetes research from Otsuka Pharmaceutical Co., Ltd., and a grant from the Mochida Memorial Foundation for Medical and Pharmaceutical Research.

\section{References}

1. Gepts, W. 1965. Pathological anatomy of the pancreas in juvenile diabetes mellitus. Diabetes. 14:619-633.

2. Junker, K., J. Egeberg, H. Kromann, and J. Nerup. 1977. An autopsy study of the islets of Langerhans in acute-onset juvenile diabetes mellitus. Acta. Pathol. Microbiol. Scand. Sect. A. 85:699-706.

3. Foulis, A. K., C. N. Liddle, M. A. Farquharson, J. A. Richmond, and R. S. Weir. 1986. The histopathology of the pancreas in type 1 (insulin-dependent) diabetes mellitus: a 25 -yr review of deaths in patients under 20 years of age in the United Kingdom. Diabetologia. 29:267-274.

4. Bottazzo, G. F., B. M. Dean, J. M. McNally, E. H. MacKay, P. G. F. Swift, and D. R. Gamble. 1985. In situ characterization of autoimmune phenomena and expression of HLA molecules in the pancreas in diabetic insulitis. $N$. Engl. $J$ Med. 313:353-360.

5. Foulis, A. K., and M. A. Farquharson. 1986. Aberrant expression of HLADR antigens by insulin containing beta cells in recent onset type 1 (insulin-dependent) diabetes mellitus. Diabetes. 35:1215-1224.

6. Foulis, A. K., M. A. Farquharson, and R. Hardman. 1987. Aberrant expression of class II major histocompatibility complex molecules by B cells and hyperexpression of class I major histocompatibility complex molecules by insulin containing islets in type 1 (insulin-dependent) diabetes mellitus. Diabetologia. 30:333-343.

7. Hanafusa, T., A. Miyazaki, J. Miyagawa, S. Tamura, M. Inada, K. Yamada, Y. Shinji, H. Katsura, K. Yamagata, N. Itoh. 1990. Examination of islets in the pancreas biopsy specimens from newly diagnosed type 1 (insulin-dependent) diabetic patients. Diabetologia. 33:105-11.

8. Townsend, A., and H. Bodmer. 1989. Antigen recognition by class I-restricted T lymphocytes. Ann. Rev. Immunol. 7:601-624.

9. Makgoba, M. W., M. E. Sander, and S. Shaw. 1989. The CD2-LFA-3 and LFA-1-ICAM-1 pathways: relevance to T-cell recognition. Immunol. Today $10: 417-422$.

10. Springer, T. A. 1990. Adhesion receptors of the immune system. Nature (Lond.). 346:425-434.

11. National Diabetes Data Group. 1979. Classification and diagnosis of diabetes mellitus and other categories of glucose intolerance. Diabetes. 28:10391057.

12. Kobayashi, T., T. Itoh, K. Kosaka, K. Sato, and K. Tsuji. 1987. Time course of islet cell antibodies and $\beta$-cell function in non-insulin-dependent stage of type I diabetes. Diabetes. 36:510-517.

13. Itoh, N., T. Hanafusa, H. Katsura, K. Yamamoto, A. Takeda, A. Kurahashi, T. Nabika, A. Miyazaki, J. Miyagawa, N. Kono, and S. Tarui. 1991. Two types of autoantibodies to adrenal medullary cells in type 1 (insulin-dependent) diabetic patients: prevalence, properties, and implications. J. Autoimmun. 4:807-818.

14. Shaw, S., G. E. G. Luce, R. Quinones, R. E. Gress, T. A. Springer, and M. E. Sanders. 1986. Two antigen-independent adhesion pathways used by human cytotoxic T-cells clones. Nature (Lond.). 317:262-264.

15. Yamagata, K., H. Nakajima, T. Hanafusa, T. Noguchi, A. Miyazaki, J. Miyagawa, M. Sada, H. Amemiya, T. Tanaka, N. Kono, and S. Tarui. 1989. Aspartic acid at position 57 of DQ $\beta$ chain does not protect against type 1 (insulin-dependent) diabetes mellitus in Japanese subjects. Diabetologia. 32:762-764.

16. Itoh, N., T. Hanafusa, J. Miyagawa, S. Tamura, M. Inada, S. Kawata, N. Kono, and S. Tarui. 1992. Transthyretin (prealbumin) in the pancreas and sera of newly diagnosed type 1 (insulin-dependent) diabetic patients. J. Clin. Endocrinol. Metab. 74:1372-1377.

17. Sibley, R. K., D. E. R. Sutherland, F. Goetz, and A. F. Michael. 1985. Recurrent diabetes mellitus in the pancreas iso- and allograft. A light and electron microscopic and immunohistochemical analysis of four cases. Lab. Invest. 53:132-144.

18. Santamaria, P., R. E. Nakhleh, D. E. R. Sutherland, and J. J. Barbosa. 1992. Characterization of $T$ lymphocytes infiltrating human pancreas allograft affected by isletitis and recurrent of diabetes. Diabetes. 41:53-61.

19. Hanninen, A., S. Jalkanen, M. Salmi, S. Toikkanen, G. Nikolakaros, and O. Simell. 1992. Macrophages, T cell receptor usage, and endothelial cell activation in the pancreas at the onset of insulin-dependent diabetes mellitus. J. Clin. Invest. 90:1901-1910. 
20. Bendelac, A., C. Carnaud, C. Boitard, and J. F. Bach. 1987. Syngeneic transfer of autoimmune diabetes from diabetic NOD mice to healthy neonates. Requirement for both L3T4 ${ }^{+}$and Lyt2 ${ }^{+}$T cells. J. Exp. Med. 166:823-832.

21. Miller, B. J., M. C. Appel, J. J. O'Neil, and L. S. Wicker. 1988. Both the $\mathrm{Lyt} 2^{+}$and $\mathrm{L} 3 \mathrm{~T}^{+}{ }^{+} \mathrm{T}$ cell subsets are required for the transfer of diabetes in nonobese diabetic mice. J. Immunol. 140:52-58.

22. Christianson, S. W., L. D. Shultz, and E. H. Leiter. 1993. Adoptive transfer of diabetes into immunodeficient NOD-scid/scid mice. Relative contributions of $\mathrm{CD}^{+}{ }^{+}$and $\mathrm{CD} 8{ }^{+} \mathrm{T}$-cells from diabetic versus prediabetic NOD.NONThy- $1^{2}$ donors. Diabetes. 42:44-55.

23. Hayakawa, M., K. Yokono, M. Nagata, N. Hatamori, W. Ogawa, A. Miki, H. Mizoguti, and S. Baba. 1991. Morphological analysis of selective destruction of pancreatic $\beta$-cells by cytotoxic T lymphocytes in NOD mice. Diabetes. 40:1210-1217.

24. Oshilewski, U., U. Kiesel, and H. Kolb. 1985. Administration of silica prevents diabetes in BB-rats. Diabetes. 34:197-199.

25. Lee, K. U., K. Amano, and J. Y. Yoon. 1988. Evidence for initial involvement of macrophage in development of insulitis in NOD mice. Diabetes. 37:989991.

26. Hutchings P., H. Rosen, L. O'Reilly, E. Simpson, S. Gordon, and A Cooke. 1990. Transfer of diabetes in mice prevented by blockade of adhesionpromoting receptor on macrophages. Nature (Lond.). 348:639-642.

27. Wang, Y., O. Pontesilli, R. G. Gill, F. G. La Rosa, and K. J. Lafferty. 1991 The role of $\mathrm{CD}^{+}$and $\mathrm{CD} 8{ }^{+} \mathrm{T}$ cells in the destruction of islet grafts by spontaneously diabetic mice. Proc. Natl. Acad. Sci. USA. 88:527-531.

28. Bedossa, P., A. Bendelac, J. F. Bach, and C. Carnaud. 1989. Syngeneic T cell transfer of diabetes into NOD newborn mice: in situ studies of the autoimmune steps leading to insulin-producing cell destruction. Eur. J. Immunol. 19:1947-1951.

29. Kay, T. W. H., I. L. Campbell, L. Oxbrow, and L. C. Harrison. 1991 Overexpression of class I major histocompatibility complex accompanies insulitis in the non-obese diabetic mouse and is prevented by anti-interferon- $\gamma$ antibody. Diabetologia. 34:779-785.

30. Pujol-Borrell, R., I. Todd, M. Doshi, D. Gray, M. Feldmann, and G. F. Bottazzo. 1986. Differential expression and regulation of MHC products in the endocrine and exocrine cells of the human pancreas. Clin. Exp. Immunol. 65:128-139.

31. Foulis, A. K., M. McGill, and M. A. Farquharson. 1991. Insulitis in type 1 (insulin-dependent) diabetes mellitus in man-macrophages, lymphocytes, and interferon- $\gamma$ containing cells. $J$. Pathol. 165:97-103.

32. Foulis, A. K., M. A. Farquharson, and A. Meager. 1987. Immunoreactive alpha-interferon in insulin-secreting beta cells in type 1 diabetes mellitus. Lancet. ii: $1423-1427$.

33. Zheng, R. Q. H., E. R. Abney, B. Grubeck-Loebenstein, C. Dayan, R. N. Maini, and M. Feldmann. 1990. Expression of intercellular adhesion moleculeand lymphocyte function-associated antigen-3 on human thyroid epithelial cells in Graves' and Hashimoto's disease. J. Autoimmun. 3:727-736.

34. Hale, L. P., M. E. Martin, D. E. McCollum, J. A. Nunley, T. A. Springer, K. H. Singer, and B. F. Haynes. 1989. Immunohistologic analysis of the distribution of cell adhesion molecules within the inflammatory synovial microenvironment. Arthritis Rheum. 32:22-30.

35. Lampeter, E. R., T. K. Kishimoto, R. Rothlein, E. A. Mainolfi, J. Bertrams, H. Kolb, and S. Martin. 1992. Elevated levels of circulating adhesion molecules in IDDM patients and in subjects at risk for IDDM. Diabetes. 41:1668-1671.

36. Campbell, I. L., A. Cutri, D. Wilkinson, A. W. Boyd, and L. C. Harrison. 1989. Intercellular adhesion molecule 1 is induced on isolated endocrine islet cells by cytokines but not by reovirus infection. Proc. Natl. Acad. Sci. USA. 86:4282-4286

37. Vives, M., G. Soldevila, L. Alcalde, C. Lolenzo, N. Somoza, and R. PujolBorrell. 1991. Adhesion molecules in human islet $\beta$-cells: de novo induction of ICAM-1 but not LFA-3. Diabetes. 40:1382-1390. 